\title{
The Effect of Teaching Pragmatic Discourse Markers on EFL Learners' Listening Comprehension
}

\author{
Bahador Sadeghi (Corresponding Author, PhD) \\ Department of English, Faculty of Foreign Languages \\ Takestan Branch, Islamic Azad University, Takestan, Iran \\ E-mail:bahsad@gmail.com \\ Hooshyar Heidaryan(M.A.) \\ Department of English, Faculty of Foreign Languages \\ Takestan Branch, Islamic Azad University, Takestan, Iran \\ E-mail: h.heidaryan@yahoo.com
}

Received: November 17, 2012

Accepted: November 30, 2012

Published: December 20, 2012

doi:10.5430/elr.v1n2p165

URL: http://dx.doi.org/10.5430/elr.v1n2p165

\begin{abstract}
This study was conducted to investigate the effect of teaching pragmatic discourse markers on EFL learners listening comprehension of Iranian Advanced EFL learners. For this purpose, 50 Male and Female learners of English in the Payam-Noor University of Songhor Branch participated in this study whose major was English Translation. For the purpose of teaching discourse markers, fourteen sessions were allocated. After an intervention period of twelve weeks, where the experimental group received strategy training in recognition of discourse markers in Audio-texts ( short stories level 6), experimental and control groups again were tested through multiple choice questions in post-test stage, and their results were quantatively compared. Based on analysis and description of data, results showed that the two Experimental and Control groups had a performance difference from each other in post-test and pre-test of this study. So multiple choice questions analyses provided developmental patterns of EFL participants with a listening comprehension proficiency increase. In the meantime, further research seems to be necessary to test the findings of this study and to determine whether materials and instruction used by the students to recognize and interpret discourse markers in academic content lectures bring about a higher level of listening comprehension.
\end{abstract}

Keywords: EFL learners, Markers, Discourse markers, Listening comprehension

\section{Introduction}

Communication in a second or foreign language is important because by this way, ideas, and point of views are revised and transferred from one person to the other. Communication is established when the speaker and listener pay considerable attention to all factors that may impact interpretation pragmatically. These factors are features of situation, discourse markers, cohesive ties, transactional and interactional views, and so on.

Widdowson (2007) identifies three key terms in communication; the first is context that is the common knowledge of two people concerned which is established in their previous conversation and is an abstract representation of a state of affair. The second is discourse which refers to both what a text producer means by a text and what a text means to the receiver and it relates to broader issues of what social and ideological values they subscribe to text. The third is the text as a purposeful use of language without necessarily being able to interpret just what is meant by it.

One of the factors which has a key role in the context is the discourse marker. Sometimes the speaker does not need to use a complete sentence in order for the listener to understand what he said but he can use incomplete phrases or words in initiating, maintaining, and ending his conversation; these are Discourse Markers (DMs). According to Aijmer (2009), for a newcomer to the field, it is often very difficult to find the bits and pieces that constitute an original model of the meanings and functions of discourse particles. Schiffrin (as cited in Aijmer, 2009), characterizes discourse markers as deictic and suggests that they have indexical functions. What discourse markers or pragmatic markers generally do is to indexically point to features of the context. 
In this study, the researchers explore the effect of teaching of pragmatic discourse markers on English Foreign Language (EFL) learners listening comprehension. In this study, what are important are the applications and the roles of markers as key elements in discourse and how they will affect listeners, in understanding and inferring speakers' utterances pragmatically and contextually.

\subsection{Statement of problem}

The structures of the lecture as well as transition stages in the lectures are often indicated through the use of discourse markers such as "let us look at the following". These devices work at a discourse level and are not dependent on the smaller unites of talk (sentences) of which discourse is composed. Trillo (as cited in Chen, 2004) states, pragmatic competence purposefully is a must because non-native learners often develop their grammatical ability away from their pragmatic one but these DMs have often been neglected by the teachers and textbooks. A lack of DMs found from the textbooks could be a source of students' inadequate DM ability. Castro (2009) in his study says, the fact that most of the studies on DMs have focused their attention on native (or bilingual) speakers of English who acquire this pragmatic competence in their childhood might be an indicator of the need to further explore and systematically investigate the language used by non-native English teachers.

Anyway, whether teaching of discourse markers have any effect on EFL learners listening comprehension, there are different views on this issue expressed by the researchers. So, because of the importance of DMs, this study tries to investigate the potential effect of these elements on listening comprehension of Iranian EFL learners.

\subsection{Significance of study}

As Muller (2005) stated, there is an agreement that discourse markers contribute to the pragmatic meaning of utterances and thus play an important role in the pragmatic competence of speaker. Crystal (as cited in Muller, 2005) gives comments, I tend to think of [pragmatic expressions such as "you know"] as the means which helps us perform the complex task of spontaneous speech production and interaction smoothly and efficiently.

Increased awareness on the textual functions of DMs could facilitate the structuring and organization of the practitioners' lesson, as signals of the main segments (e.g. frame markers) and perform a number of organizational functions such as floor management (e.g. turn takers and turn givers). Furthermore, in Iran the learners of English are EFL learners have a great problem in listening comprehension; Moreover teachers are Non- Natives, and therefore the importance of DM is beyond doubt. In this study, the researchers try to evaluate the effect of teaching pragmatic discourse markers on EFL students' listening comprehension.

\section{Review of Related Literature}

\subsection{Listening comprehension}

Rubin (1995) conceived listening as "an active process in which a listener selects and interprets information which comes from auditory and visual clues in order to define what is going on and what the speakers are trying to express" (p. 151). Purdy (1991) defined listening as "the active and dynamic process of attending, perceiving, interpreting, remembering, and responding to the expressed (verbal and nonverbal) needs, concerns, and information offered by other human beings". Listening is "complex, dynamic and fragile" (Celce- Murcia, 2001).

Listening comprehension has been neglected in research and practice until quite recently. However it is true that listening is a vital component in language learning in that it provides input for the learner. The main aim in teaching students how to understand English as it is normally spoken by the native English speakers is to make the students aware of what signals they can depend on hearing in the stream of speech and to make them use those signals(Saricoban, 1999).

Listening to lectures is the most urgently needed as it is the main mode of information transfer. Academic listening skills are thus an essential component of communicative competence. Problematic features in listening to lectures that inhibit lecture comprehension warrant investigation (Philip, 2011).

\subsection{Defining of discourse markers}

Harmer (2007) maintained discourse markers are used to buy time, to start a turn, or to mark the beginning or end of a segment through the use of grammar and vocabulary, highlight the dependence of learners' successful execution of turn taking, through the correct use of discourse markers, for successful spoken interaction. In the other place, by the definition of Rowling (2002), discourse markers are the lexical items which are used by the speaker to comment upon the discourse plan and goals. From viewpoints of Bonamy and Hafherr (2004), discourse markers are used in

conversational speech more than in any other form of communication. Rowling (2002) says, Fraser's article also reminds us that discourse markers as a subcategory of discourse analysis are still a fairly new topic. It is not always 
easy to define what words have a secondary use as a DM, especially since it differs even within one language due to location, dialect, age, social class and other factors which will not be considered in depth in this thesis. Discourse markers have a key role in understanding and recognition of listening comprehension. Research has shown that the introduction of appropriate discourse markers as well as training students to recognize and interpret them may assist the lecture in ensuring that his/her intended meaning is conveyed (Chaudron and Richard, 1986).

\subsection{The role of the discourse markers}

There have been also some researches on the role of DMs on listening comprehension, including the one among done by Eslami and Eslami-Rasekh (2007). In this study, two groups of students listened to two different versions of a lecture. The two versions were different according to the quantity and type of discourse markers. Listening comprehension tests and their mean scores were compared and the findings clearly indicated that subjects comprehended the lecture better when discourse markers were included than when they were omitted. According to Jung (2004), the rhetorical devices that signal the information structure of text are called organization markers, and these include macro- and micro-markers. Macro-markers are markers of higher-order information, which signal the relationship between the major propositions or mark the important transition points in the discourse (e.g., "What I'm going to talk about today is...," "The next thing is...," "Let me summarize," etc.). On the other hand, micro-markers are markers of lower-order information, which mark intersentential relations or function as pause fillers (e.g., "but," "so," "well," etc).

\subsection{Macro \& micro markers}

According to Which (1986), discourse markers are divided in two groups. Now we will have a closer look at their classification; Macro DMs and Micro DMs. Macro DMs indicate the overall organization of lectures through highlighting major information and sequencing or importance of that information. To clarify, they are the signals or meta-statements about the major propositions. On the contrary, micro - markers such as 'well', 'so', 'now', 'you know' are those which indicate link between sentences within the lecture or which function as filler. Micro-markers signal lower level of information in the text. They are principally used to fill pauses giving listeners more time to process pieces of discourse (Sadri 2010). Alam and Sinha (2009), and Chaudron and Richards (1986 in Jordan1997) show that the traditional "reading style" lecture contain two types of discourse markers - the macro markers and the micro markers. They noticed that the macro makers signal significant transitions in the lecture whereas the micro markers are used as intersentential connectors. Decarrico and Nattinger (1988 in Jordan, 1997: 185) also express a similar view. They suggest that macro organizers such as topic-markers, topic-shifters, summarizers, amplifiers, relators, evaluators, qualifiers and aside markers play significant roles in lectures.

\subsection{Teaching of discourse markers}

Regarding teaching of markers in writing, the findings of Dastjerdi and Shirzad(2010), attempted to determine the effect of explicit instruction of meta-discourse markers on pre-intermediate Iranian EFL learners' reading comprehension skill. There was also a significant relationship between highly rated essays and poorly rated ones in the frequency use of elaborative, contrastive and topic relating discourse markers. Lee and Hsieh (2004), reviewed related representative literature to support the assumption and to delimit certain fundamental speech functions of "well, you know and I mean" to meet the pedagogical need. In addition, they demonstrated the feasibility of teaching DMs in $\mathrm{L} 2$ language classrooms by providing potential teaching activity designs.

\subsection{Pragmatic markers and pragmatic discourse}

One study has been conducted on pragmatic markers in an actual context by Wang (2005), shows that in some instances, whereas many studies have dealt with the pragmatic functions of specific discourse markers, less attention has been paid to the patterns of these functions found in different discourse modes. Moreover, this study shows that the text type also plays a role in the use and distribution of these contrastive markers. Haig (2008) makes it clear by giving an example (radio news) on the relationship between contextual discourse and listening comprehension skill. It is generally acknowledged that news texts have great ideological significance in contemporary societies and the production and dissemination of news texts by mass media organizations and their consumption by audiences are key processes in the operation of ideology.

\subsection{Issues on EFL learners and instruction in FL}

Regarding listening as a complimentizer skill for spoken language, Lewier (2009) points out that listening in the EFL classroom are unnatural. The contrived speech environment of the EFL classroom causes a problem for learners to accustom themselves to spontaneous English speech which is not produced for teaching and learning purposes in school setting. In responding to the above mentioned problems, this article discusses the use of advance organizer 
can be defined as an approach that aids the process of learning. Chung (2006, p. 142) explains that advance organizer is an overview or summary of information that is organized in advance and is presented before the learners have approached the task .So, the advanced organizer technique, in its many varieties, enable EFL teachers to tap into learners motivation and is beneficial in enhancing EFL learners listening comprehension. Advanced organizers give students sufficient information related to the listening tasks and activate their background knowledge and help comprehend spoken language.

Liang (2002) defines and describes his method as such for teaching English as foreign language. "Cooperative learning" is a feasible teaching method with characteristics compatible with the current wave of educational reform, especially with the aim of fostering the basic competencies of our students. According to the study by Dastjerdi and Rezvani (2010), it was revealed that both explicit and implicit instructions have a positive impact on the acquisition of the target forms. The results demonstrating that the learners who received implicit instruction made significant gains with regard to the production of requests concurs with the general findings in earlier studies on the facilitative effects of input enhancement. Vasiljevic (2010), in teaching of EFL listening, applies the dictogloss, but what is important that this method can be done according to Vasiljevic: Listening requires the utilisation of both systemic (i.e. an understanding of the phonological, syntactic and semantic aspect knowledge) and schematic knowledge (general knowledge of the world) (Widdowson, 1983). A dictogloss listening class embodies several important principles of language learning such as learner autonomy, cooperation among learners; focus on meaning and self and peer-assessment. Process is equally as important as product. According to what has been studied and read in Inggris (2008) is that, one of the famous issues in EFL learning is competence and performance; competence refers to the abstract and unseen representation of language knowledge inside our mind, with its probability to make and comprehend original utterances in a given language.

Finally, it is believed that the underlying paradox in the effect of teaching DMs on listening comprehension research is the routine unconscious ease of listening and the extreme difficulty of investigating it, particularly as the process is unseen and inaccessible. More research around the effect and the role these signal markers in comprehension of the spoken lectures (FL) is essential. Research into the lecture comprehension process is thus valuable. In addition, information about listening comprehension strategies can be employed to make content lectures aware of how discourse markers can facilitate students understanding of subject content in spoken lectures.

\section{Research question}

Research question:

1) Does teaching of pragmatic discourse markers have any effect on EFL listening comprehension or not?

\section{Methodology}

\subsection{Participants}

This study was conducted with 50 EFL students in BA Level of University. These participants were randomly assigned to two groups, the "experimental and control" groups. In the Experimental class, discourse markers were taught and in the control class, discourse markers were not taught. Two groups were selected from intact classes where each student had an equal chance of being selected. They were both male and female ( 25 males and females in experimental group and 25 males and females in control group) and the age range was between 18 to 25 . This study was conducted at the University of Payam-Noor of Songhor Branch. Their major was English translation and their level was the fifth semester and higher.

\subsection{Materials}

This study was conducted by collecting data from intact classes of university students by means of a pre-test treatment program- post-test design in order to investigate whether teaching of discourse markers has an effect on EFL learners listening comprehension. This was measured by scores in multiple choice questions.

\subsection{Procedure}

To test the research hypothesis, it was designed tests based on the content of an authentic conversation; these tests were taken from TOEFL listening tests, advanced level (Gallagher, 2006). In pre-test, it was taken care to include about 600 words and expressions constituting mainly macro-markers in the texts. These words and phrases indicated the overall structure of the conversation. Examples of macro-markers used in the conversation texts were; "I will point out...", by this mean......", this was then in short..." The conversations were delivered in clear, standard, academic English at the normal speaking pace (Mason, 1994) which is regarded as approximately a 150 words per 
minutes. In preparation of the tests setting, extraneous, confounding variables such as background noise which might have had an influence on the results, were identified and eliminated.

After conducting the pre-test, the total marks scored were analyzed by the participants and compared the mean scored in order to determine whether there existed a significant difference between the results of the experimental and control group. In the pre- and post-intervention tests, an objective approach was maintained to data collection. Students were identified only by student numbers and remained distant from them as individuals.

The intervention began directly after the pre-test was done. The participants in experimental group have been taught in interpretation and recognition of DMs that they used in lectures during short time. Students were sensitized to the existence and function of discourse markers as far as they contributed to the macro- structure of the lecture. Audio-recorded texts had advantage that students who had missed a particular session could attend exactly the same lecture content in their own time. The use of audio-recorded texts had an added advantage as it contributed to the explicability of this study. During the intervention sessions which have taken place on the same day each week in the same time slot, it has been attempted to keep all the physical conditions as similar as possible. Two weeks after the intervention program had been completed both the experimental and the control groups were tested by the post-intervention test and these results have been analyzed. Also, the same procedure was followed for the post-test as pre-test.

\subsection{Design}

In designing the test instrument based on the research approach, a standardized test as TOEFL test was chosen. It included 20 multiple choice questions and the specified time for test was 20 minutes. Also, it should be noted that each question had an interval score (5 points) and wholly 100 points was specified to each test. But, in designing of intervention program, it included 12 weeks, 14 lecture sessions (reference: the Enemy stage 6, short stories). The duration of each session was 45 minutes. Each chapter was started by mentioning and discussing the particular discourse markers used in that specific lecture.

\subsection{Data analysis}

The means of the experimental and the control groups performances in the pre-and post-tests were compared to determine whether there was a significance improvement in the test scores. Then an independent $t$-test was conducted: it made use of t-test to compare the results of two groups and an independent t-test was employed to assess whether the scores in each of the test sections differed significantly from that of the control groups of participants. Also, the ratios of skewness and kurtosis were used for measuring the assumption of normality.

\section{Results and Discussion}

\subsection{Testing Assumptions}

Four assumptions of interval data, independence, normality and homogeneity of variances should be met before running any parametric tests to analyze any sets of data (Field; 2009). The present data were measured on an interval scale, i.e. they are tests' scores obtained through the study and the subjects are independent, i.e. none of them participated in more than one group.

The assumption of normality as measured through the ratios of skewness and kurtosis over their respective standard errors are displayed in Table 1. The ratios of skewness and kurtosis over their standard errors are all within the ranges of plus and minus 1.96 (Field; 2009). Based on these results, it can be concluded that the present data enjoy normal distributions.

Pre-test of Listening Comprehension:

An independent t-test is run to compare the mean scores of the experimental and control groups on the pretest listening comprehension test.

The t-observed value is .32 (Table 1). This amount of t-value is lower than the critical value of 2.01 at 48 degrees of freedom. Based on these results it can be concluded that the experimental and control groups were homogenous in terms of their listening comprehension ability prior to the administration of pragmatic discourse markers to the experimental group.

It should be noted that the two groups are homogenous in terms of their variances. The Levene's F-value of 1.14 is not significant $(\mathrm{P}=.290>.05)$. That is why the first row of Table 3, "Equal variances assumed" reported.

Table 2 displays the mean scores for the experimental and control groups on the pretest of listening comprehension. The mean scores for the experimental and control are 52 and 50.40 respectively. 


\subsection{Research Question}

Does the teaching of pragmatic discourse markers have any effect on EFL learners listening comprehension?

An independent t-test is run to compare the mean scores of the experimental and control groups on the posttest listening comprehension test in order to probe the effect of pragmatic discourse markers on the improvement of the listening comprehension ability of the EFL learners.

The t-observed value is 3.52 (Table 3). This amount of t-value is higher than the critical value of 2.01 at 48 degrees of freedom. Based on these results, it can be concluded that there is a significant difference between the experimental and control groups' mean scores on the posttest of listening comprehension. Thus the null-hypothesis that the teaching of pragmatic discourse markers does not have any effect on EFL learners listening comprehension is rejected.

It should be noted that the two groups are homogenous in terms of their variances. The Levene's F-value of .174 is not significant $(\mathrm{P}=.678>.05)$. That is why the first row of Table 3, "Equal variances assumed" reported.

Table 4 displays the mean scores for the experimental and control groups on the posttest of listening comprehension. The mean scores for the experimental and control are 63.40 and 44.60 respectively. The experimental group outperformed the control group on the posttest of listening comprehension.

Table 5 (integrate table) shows a performance difference between two groups: In pre-test, performance difference between control and experimental is not much but in post-test, it is considerable and salient.

\subsection{Testing hypothesis}

H- Teaching of pragmatic discourse markers does not have any effect on EFL learners listening comprehension

It was showed both groups were taught Audio-recorded conversations ( TOEFL listening tests) and tested on the content ( mostly between two persons, professor \& student, in class) to determine whether there would be any difference in the listening comprehension abilities of the experimental and control groups before the intervention. The test was standardized tests that its format was multiple choices (To minimize the necessity for written answers). The test measured skill of students: Details, main idea, summaries, inference, in other word, it assessed the participants' abilities to recall content information from different angles. The results of the students gave an indication of their academic listening comprehension proficiency before the commencement of the intervention program.

To establish whether the experimental group had benefited significantly or not from the twelve weeks intervention program, both groups of students were tested by the other Audio-recorded conversations (different, but in the same level as pre-test). Their test results were statistically analyzed and compared with the previous test.

But in multiple choice questions, it was assessed whether the participants were able to select details or infer content introduced by means of discourse markers from spoken tests. The aim of the multiple choice questions was to establish whether bits of information highlighted by means of discourse markers were easier for students to assimilate, should they be aware of the role discourse markers play in simplifying the lecture texts. It was thus important to establish whether the experimental group performed differently in this section in the pre-and post- tests. The performance of the control group in the same tests was used as a control measure to determine the effect of awareness-raising in the experiment.

Again it was looked at the performance of both groups in this section of the pre-test to determine whether was any significance difference between the two groups at the beginning of the program. Then, the performance of the experimental group was compared in the two tests to determine any significance improvement had occurred in this section of the post-test or not. It subsequently has been done the same for the control group. Further, the results of the two groups were compared with each other to establish whether the experimental group performed significantly differently from the control group or not.

\subsection{Discussion}

With regard to the analysis of the data in the previous section and the results, therefore the following significant conclusion can be drawn and discussed: English foreign Language (EFL) learners had the highest improvement. In other words, instruction showed to be most effective for this group of learners. The above conclusions confirm the major claim of this research that instruction of metadiscourse markers in Iranian EFL courses is quite successful for improving learners' listening ability. This strongly corresponds to Crismore's (1985) point of view that metadiscourse awareness has been very effective in foreign and second language teaching classrooms and with 
various parts of language skills and components. As it was also observed in the preceding section, the participants in the experimental group did significantly better than the control group on their

post test- an unpredictable finding. This is in contrast to Simin and Tavangar's (2009) finding that" the more proficient learners are in a second language, the more they use metadiscourse markers"(p. 230).

The outperformance of EFL learners in the present study and the possible reasons for it should however be investigated in future researches and different contexts. The findings of this research reveal the fact that discourse awareness affects the learners' language comprehension. This is in line with studies of Cheng and Steffensen (1996) and Intraprawat and Steffensen (1995) who have come to the point that students' listening is improved when they listen with an awareness of textual metadiscourse--one of the two types of metadiscourse markers taught in this research. The findings also support Simin and Tavangar's (2009) statement that, "metadiscourse instruction has a positive effect on the correct use of discourse markers" (230), although there is no report in their study of teaching of discourse markers to their participants. The findings are also in line with Perez- L1antada (2003), who conducted research on the effect of metadiscourse techniques on learners' communication skills in university courses of English for Academic Purposes (EAP), and observed that students became successful communicators with regards to metadiscourse strategies.

The findings of this study seemed to correspond to those of Khuwaleih (1999). She found that students' failure was due to a lack of understanding academic lectures rather than to an inability to comprehend the subject content conveyed in the lectures. So, our hypothesis is not accepted as predicted students comprehend a lecture will not be better when they are aware of discourse markers and the role they play in structuring lecture text.

Also, this study agrees with Field (1998) that spending time on helping students tackle their listening problems is an important part of teaching listening. It is crucial that course designers include practice activities in their course design to help students overcome or cope with listening comprehension difficulties. The outcome of this study clearly shows the benefits of an awareness-raising program and accompanying practice activities.

Two approaches for studying DMs have been investigated. In the first approach, Giora (1998) maintains that DMs are linguistic expressions that relate discourse units. Proponents of this approach analyze DMs as cohesive devices that contribute to the coherence of well-formed discourse by encoding cohesive (semantic) relationships between discourse units. But in the second approach, Wilson (1998) explains DMs as pragmatic devices that contribute to the interpretation and comprehension of utterance by encoding procedural information that control the choice of contextual information. In other words, such devices encode relevance relations between propositions (thoughts) and the cognitive environment of an individual.

It seems that there is something in common between the two approaches. The coherence approach has two goals. Firstly, it aims to provide a theory of comprehension of discourse, i.e. how discourse is understood and interpreted. Secondly, it is concerned with providing a theory of evaluation and explanation the intuition of discourse well-formedness. It is obvious that the relevance approach shares the first goal with the coherence approach since relevance theory's main objective is to explain how utterances are understood.

The coherence approach suggests that the best way to account for discourse interpretation is to look at coherence relations between topics in discourse. By contrast, the relevance approach argues that the recognition of coherence relations between discourse topics is neither necessary nor sufficient condition for a successful discourse. What is needed for a comprehensible interpretation of discourse is the recognition of contextual (cognitive) effect held in that discourse. As for the second goal, Relevance theory rejects the notion of well-formedness of discourse. Relevance theory sees that well-formedness of discourse exists only in relation to a set of well-formedness rules which are independent of individuals, situations and contexts.

It seems that that the whole dispute centers on the notion of 'well-formedness' with respect to 'discourse'. Coherence theorists such as Schiffrin and Giora argue that the well-formedness should be maintained in discourse and it is achieved by linguistic means. A certain discourse is well-formed if and only if its segments are intuitively related.

Discourse markers are cohesive ties that act as connectives and explicitly signal the structure of a piece of discourse. They are used by the speaker to indicate how what is being said related to what has already being said. They can be divided into micro- markers (Now, Well, Okay), and macro- markers (To begin with, the last word...). This study was an attempt to explore the relationship between discourse markers and listening comprehension, in a situation where academic lectures are delivered by lecturers who are non-native speakers of English, to students who are also non-native listeners. The main finding of this investigation suggests that a combination of micro and macro markers, 
used in a lecture, facilitate greater comprehension, where they use only micro markers among students of both intermediate and advanced proficiency.

\section{Conclusions}

For this study, an experiment was conducted to determine whether teaching and recognition of discourse markers will enhance students' listening comprehension in academic conversations. Students were tested to determine their comprehension in audio-recorded conversations. After intervention program where the experimental group received strategy training in the recognition and interpretation of discourse markers in spoken texts. Both groups were again tested. Their results on both pre- and post tests statistically were analyzed: learners had the highest improvement. In other words, instruction showed to be most effective for this group of learners. Also, the findings of this study have shown that instructional programs in listening comprehension will improve students' ability to cope with content information provided in lectures.

\subsection{Implications}

Our analysis shows that discourse markers provide an important first clue to the conversational move about to be made by a speaker. Our results also have implications for utterance generation in task-oriented systems. To collaborate in the same way humans do, our systems must construct utterances which signal mutual understanding of shared information and discourse structure in an appropriate way. Using discourse markers will help the system's utterances seem more natural to the user, and will help him understand the discourse intent of the upcoming move.

\subsection{Suggestions for further researches}

Listening comprehension research needs to be focused on possible supporting programs which help students become selective, effective and active listeners in academic situations. At Payam-Noor Language centre listening comprehension in academic lectures has not yet been regarded as an area of individual skills that requires specific training.

The teacher centered approach, relying much on rote- learning of the subject content, is still prevalent in a large number of Iran Universities. Every year large number of EFL learners enters universities of Iran. Much more research on the effect of teaching of discourse markers and the role they play in structuring spoken academic texts is needed.

Therefore, if school leavers are expected to be independent learners at university and to employ inferencing skills, they need to be supported in becoming critical listeners. Should they be able to determine the global structure of a lecture and critically interpret the direction a lecturer takes, they will learn to infer meaning and interpret the text rather than just receive and accept what lecturers say. The presence of discourse markers can make a positive contribution to improved academic listening proficiency as far as comprehension and recall is concerned as they orientate the listeners toward the text.

If it is to provide opportunities for the students to acquire micro- skills in listening comprehension, they need to be provided with comprehensible input and purposeful listening tasks which develop comprehension (Richards, 1983). Each intervention session in this study was specifically designed to expose the students to different categories of discourse markers. As they were first made aware of specific discourse markers and what their functions were in the lecture, they were able to recognize these markers in the lecture texts as pages onto which important content information was hung.

In order to enhance effective listening comprehension in students when they attend academic content lectures, lectures need first of all to ensure that they speak at a normal speech rate. Lectures should be well-organized, either outlines on the board or overhead projector or in the form of hand- outs. Lecturers need to be trained to insert many more overt discourse markers that highlight the overall the structure of their lectures. They could further increase the amount of redundancy by means of discourse markers indicating consecutive numbers such as "'firstly, secondly". Finally, the increased use of linguistic aspects such as discourse markers in lecture discourse can be interpreted as an effect of personalization (Morell, 2004).

So far prosodic features of pragmatic markers have been largely neglected and recent approaches now explore the possibility of integrating prosody into the analysis in a more systematic way. Prosody plays an important role in distinguishing various uses of pragmatic markers.

Another aspect, however, is that a single component of oral communication and listening comprehension is insufficient. Attention to one area ought to be complemented by attention to others as systematically as possible (Murphy, 1991). Further research is necessary to test the present findings and to determine whether materials and 
instruction used by the students to recognize and interpret discourse markers in academic content lectures bring about a higher level of listening comprehension.

A final word is that, first of all, this research can be a call to teachers, practitioners and researchers in language teaching and learning to pay more attention to metadiscourse as an important aspect of language. Secondly, it provides a suggestion to material designers, i.e. by making texts more coherent both textually and interpersonally they can enhance EFL learners' ability to understand and remember information. The outcome of this study suggests that, in future, more research needs to be done on the role of discourse markers in listening comprehension.

\section{References}

Aijmer, K. (2009). Please: A politeness formula viewed in a translation perspective. Brno studies in English, VOL, 35. NO, 2.

Alam, Z., \& Sinha, B. S. (2009). Developing listening skills for tertiary level learners. The Dhaka University Journal of Linguistics: Vol. 2 No.3, P: 19-52.

Castro, M.C. (2009). The use and functions of discourse markers in EFL classroom interaction, 57-77. Columbia; University pedagogica Nacional.

Celce- Murcia, D. (2001). Discourse analysis and the teaching of listening. In Cook, G. and Seidlhofer, B. (eds) Principle and practice in Applied Linguistic. Hong Kong; Oxford University Press.

Chaudron, C., \& Richards, J. C. (1986). The effect of discourse markers on the comprehension of lectures. Applied Linguistics, 7 (2), 113-127. http://dx.doi.org/10.1093/applin/7.2.113

Chen, W. C. S. (2004). Pragmatic discourse markers: A Comparison between Natives and Non-natives and Textbook Evaluation. National Taiwan Normal University.weizue69@yahoo.com.

Cheng, X \& Steffensen, M. (1996). Metadiscourse: A technique in improving students writing. Research in the teaching of English.

Chung, L. M. (2002). The effect of using two advance organizers with video texts for the teaching listening in English. Foreign Language Annals, 38(4), 505- 513.

Crismore, A. (1989). Talking with readers: Metadiscourse as rhetorical act. New York: Peter Lang.

Dastjerdi, H. V., \& Rezvani, E. (2010). The Impact of instruction on Iranian intermediate EFL Learners“ production of requests in English. Journal of Language Teaching and Research; Vol, 1. No, 6. pp. 782-790. http://dx.doi.org/10.4304/jltr.1.6.782-790

Dastjerdi, H. V. \& Shirzad, M. (2010). The Impact of Explicit Instruction of metadiscourse Markers on EFL Learners' Writing Performance. The Journal of Teaching Language Skills (JTLS), Vol, 2. No, 2.

Eslami, Z. \& Eslami-Rasekh, A. (2007). Discourse markers in academic lectures. Asian EFL Journal; Vol. 9.

Field, A. (2009). Discovering Statistics Using SPSS. $3^{\text {rd }}$ ed. SAGE. London.

Field, J. (1998). Skills and strategies acquisition. Hong Kong: Oxford University Press.

Gallagher, N. (2006). Delta's key to the next generation TOEFL test: Advanced Skill Practice for the iBT. Delta Publication Company (ETS).

Giora, R. (1998). Discourse coherence is an independent notion: a reply to Deirdre Wilson. Journal of Pragmatics; 29, 75-86. http://dx.doi.org/10.1016/S0378-2166(97)00045-3

Haig, E. (2008). A critical discourse analysis of discourse strategies in reports on youth crime in UK Radio News.Vol. 4.

Harmer, J. (2007). The practice of English Language Teaching. Fourth edition. Pearson Education Limited. England.

Inggris, J. P. B. (2008). TEFL Methodology: Teaching English as Foreign Language Methodology. Unpublished MA. Dissertation. Fakultas Bahasa dan Seni; Universitas Negeri Yogyakarta.

Intraprawat, P. \& Steffensen, M. S. (1995). The Use of metadiscourse in good and poor ESL essays. Journal of Second Language Writing, 4 (3), 253-272. http://dx.doi.org/10.1016/1060-3743(95)90012-8

Khuwaleih, A. A. (1999). The role of chunks, phrases and body language in understanding Co- ordinate academic lessons. In system. Vol, 27; 249-260. http://dx.doi.org/10.1016/S0346-251X(99)00019-6 
Lee, B.C. \& Hsieh, C.J. (2004). Discourse markers teaching in college conversation classroom: Focus on well, you know, I mean; 12, 177-199. China Medical University.

Lewier, C. A. (2009). Incorporating the advance organizer technique in teaching listening to enhance EFL students' listening comprehension. Tahuri; Vol, 6. No, 2.

Liang, T. (2002). Implementing cooperative learning in EFL teaching: Process and effects. Unpublished PHD dissertation. National Taiwan University.

Llantada, C. P. (2005). Instruction and interaction in an American lecture class, observation from a corpus. The ESPecialist, Vol., 2. (205-227).

Mason, A. (1994). Student and lecture perceptions of lecture comprehension strategies in first term study. In Flowerdew, J. (ed.) Academic listening: Research perspectives. Cambridge: Cambridge University Press. 199- 218.

Morell, T. (2004). Interactive lecture discourse for university EFL students. English for Specific Purposes (23), 325-338. http://dx.doi.org/10.1016/S0889-4906(03)00029-2

Muller, S. (2005). Discourse markers in Native and Non-native English discourse. John Benjamins Publishing Company. NO 1, 138.

Philip, G. (2011). Replicating features of natural discourse in the preparation of dialogues for B1 learners. Università degli Studi di Bologna.

Richards, J. C. (1998). Teaching listening and speaking: From theory to practice.

Rowling, J. K. (2002). A Study of the translation of discourse markers in Italian in Harry Potter and the Philosopher's Stone. Sonia Mariano Linguistics and Languages. Unpublished MA.dissertation.

Rubin, J.K. (2011). A review of Second Language Listening Comprehension research. The modern language journal; 78. Hermitage Avenue Wheaton.

Saricoban, A. (1999). The teaching listening. The internet TESL Journal. Turky; Hacettepe University.

Schiffrin, D. (1987). Discourse markers. Cambridge: Cambridge University Press. http://dx.doi.org/10.1017/CBO9780511611841

Simin, S. and Tavangar, M. (2009). Metadiscourse knowledge and use in Iranian EFL writing. Asian EFL Journal, $11,230-255$.

Vasljevic, Z. (2010). Dictogloss as an interactive method of teaching listening comprehension to L2 learners. English Language Teaching; Vol, 3. No, 1. [Online] Available: www.ccsenet.org/elt.

Wang, Y. F. (2005). From lexical to pragmatic meaning: Contrastive markers in spoken Chinese discourse. Text 25(4), pp. 469-518. http://dx.doi.org/10.1515/text.2005.25.4.469

Widdowson, H.G. (1983). Learning Purpose and Language Use. Oxford: Oxford University Press.

Widdowson, G.H. (2007). Discourse Anlysis. Oxford introduction to language study. Oxford University Press.

Wilson, D. (1998). Discourse, coherence and relevance: a reply to Rachel Giora. Journal of Pragmatics 29. 57-74. http://dx.doi.org/10.1016/S0378-2166(97)00012-X 
Table 1. Pre-test of Listening Comprehension by Groups

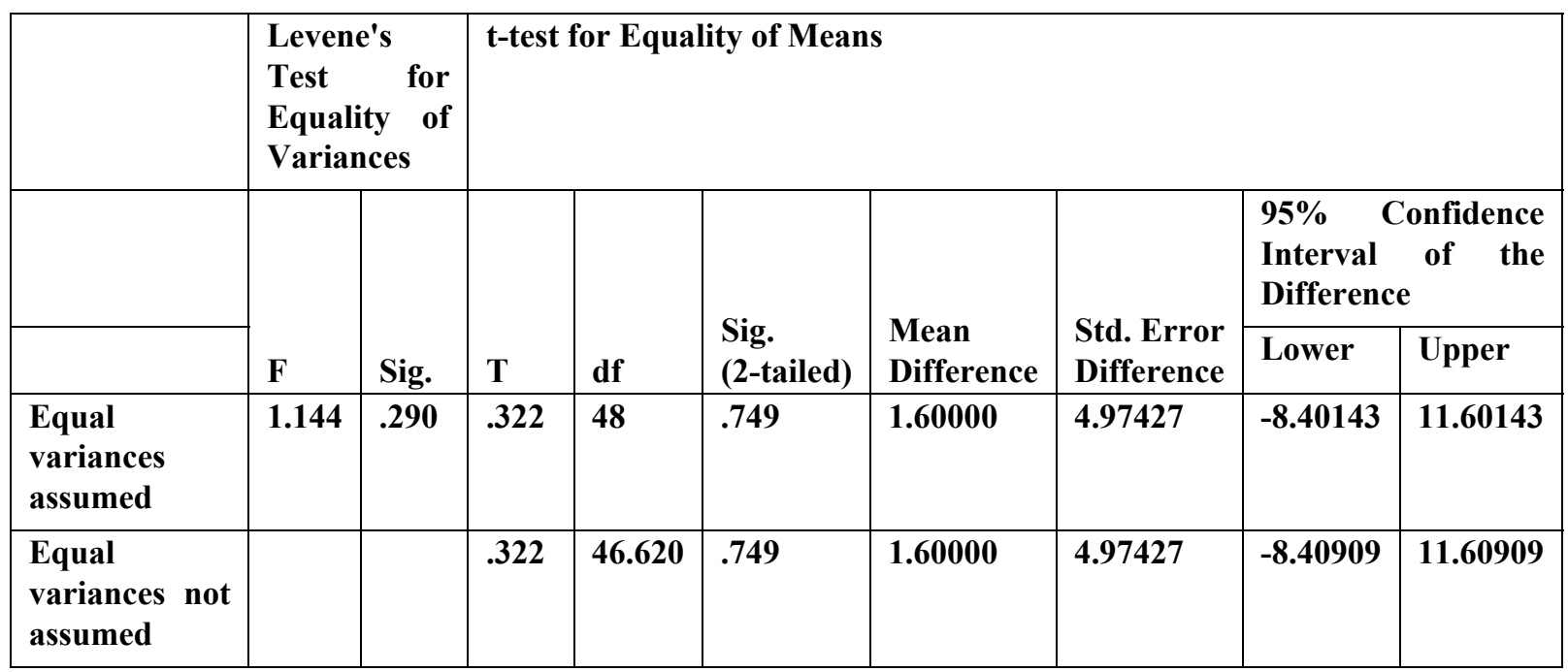

Table 2. Descriptive Statistics of Listening comprehension by Groups

\begin{tabular}{|l|l|l|l|l|}
\hline Pretest of Listening Comprehension & $\mathrm{N}$ & Mean & Std. Deviation & Std. Error Mean \\
\hline EXPERIMENTAL & 25 & $\mathbf{5 2 . 0 0 0 0}$ & $\mathbf{1 9 . 0 3 9 4 3}$ & $\mathbf{3 . 8 0 7 8 9}$ \\
\hline CONTROL & $\mathbf{2 5}$ & $\mathbf{5 0 . 4 0 0 0}$ & $\mathbf{1 6 . 0 0 2 6 0}$ & $\mathbf{3 . 2 0 0 5 2}$ \\
\hline
\end{tabular}

Table 3. Post- test Listening Comprehension test by the two Groups

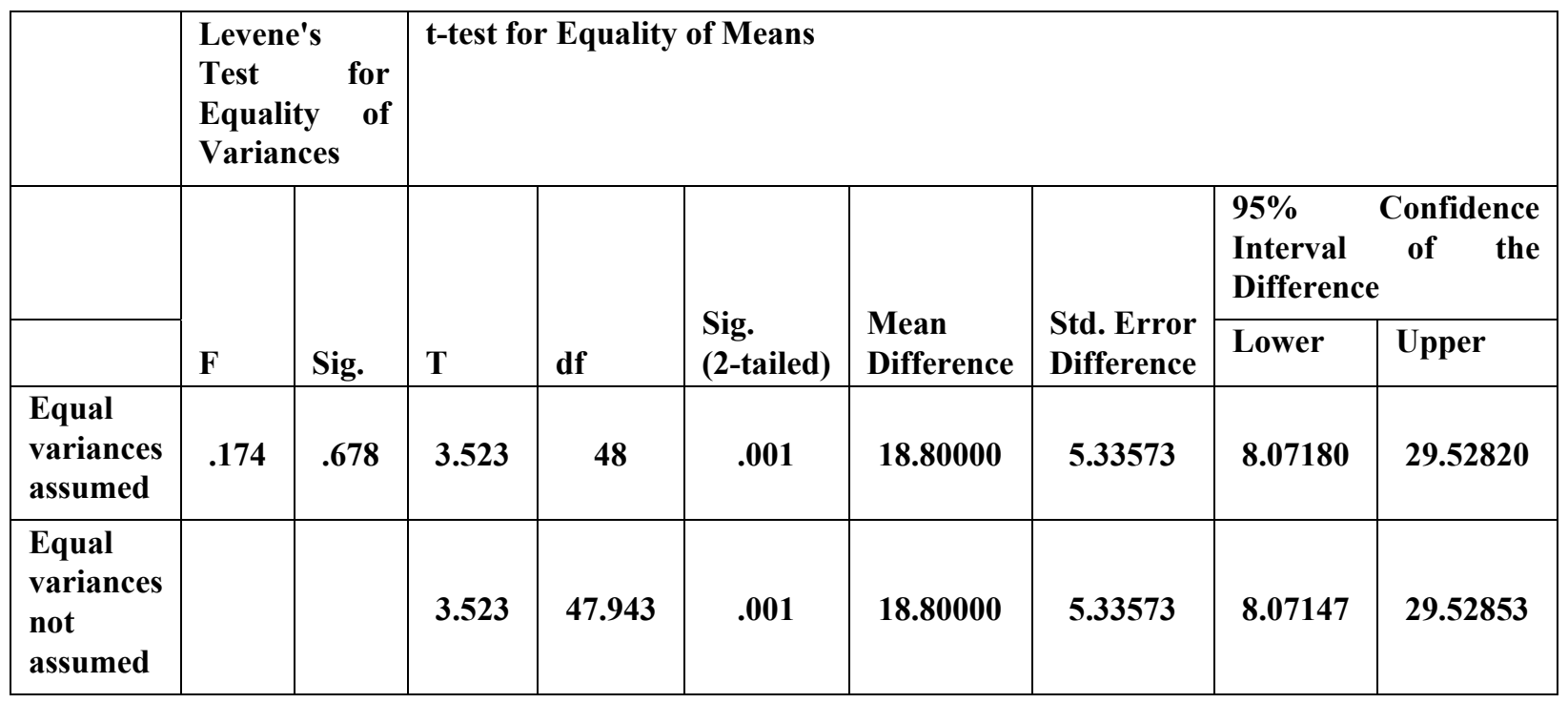


Table 4. Descriptive Statistics Listening comprehension by Groups

\begin{tabular}{|l|l|l|c|c|}
\hline Post-test of Listening Comprehension & N & Mean & Std. Deviation & Std. Error Mean \\
\hline EXPERIMENTAL & 25 & 63.4000 & 19.18767 & 3.83753 \\
\hline CONTROL & 25 & 44.6000 & 18.53600 & 3.70720 \\
\hline
\end{tabular}

Table 5. Integrated table; comparison between two groups in pre-test and post-test

\begin{tabular}{|l|l|l|l|l|}
\hline \multirow{2}{*}{ EXPERIMENTAL } & \multirow{2}{*}{$\mathbf{N}$} & \multicolumn{1}{|c|}{ Mean } & Std. Deviation & Std. Error Mean \\
& & & & \\
\hline Pre-test & 25 & $\mathbf{5 2 . 0 0 0 0}$ & $\mathbf{1 9 . 0 3 9 4 3}$ & $\mathbf{3 . 8 0 7 8 9}$ \\
\hline Post-test & 25 & $\mathbf{6 3 . 4 0 0 0}$ & $\mathbf{1 9 . 1 8 7 6 7}$ & $\mathbf{3 . 8 3 7 5 3}$ \\
\hline CONTROL & $\mathbf{N}$ & Mean & Std. & Std. Error Mean \\
& & & Deviation & \\
\hline Pre-test & 25 & $\mathbf{5 0 . 4 0 0 0}$ & $\mathbf{1 6 . 0 0 2 6 0}$ & $\mathbf{3 . 2 0 0 5 2}$ \\
\hline Post-test & 25 & $\mathbf{4 4 . 6 0 0 0}$ & $\mathbf{1 8 . 5 3 6 0 0}$ & $\mathbf{3 . 7 0 7 2 0}$ \\
\hline
\end{tabular}

